\title{
THE
}

1996

\section{Factors Affecting Interannual Movements of Snowy Plovers}

Peter W. C. Paton

University of Rhode Island, ppaton@uri.edu

Thomas C. Edwards Jr.

Follow this and additional works at: https://digitalcommons.uri.edu/nrs_facpubs

Part of the Environmental Sciences Commons, and the Ornithology Commons Terms of Use

All rights reserved under copyright.

\section{Citation/Publisher Attribution}

Peter W. C. Paton, \& Edwards, T. (1996). Factors Affecting Interannual Movements of Snowy Plovers. The Auk, 113(3), 534-543. doi:10.2307/4088973

Available at: http://dx.doi.org/10.2307/4088973

This Article is brought to you for free and open access by the Natural Resources Science at DigitalCommons@URI. It has been accepted for inclusion in Natural Resources Science Faculty Publications by an authorized administrator of DigitalCommons@URI. For more information, please contact digitalcommons-group@uri.edu. 
Factors Affecting Interannual Movements of Snowy Plovers

Author(s): Peter W. C. Paton and Thomas C. Edwards, Jr.

Reviewed work(s):

Source: The Auk, Vol. 113, No. 3 (Jul., 1996), pp. 534-543

Published by: University of California Press on behalf of the American Ornithologists' Union

Stable URL: http://www.jstor.org/stable/4088973

Accessed: 12/07/2012 11:57

Your use of the JSTOR archive indicates your acceptance of the Terms \& Conditions of Use, available at http://www.jstor.org/page/info/about/policies/terms.jsp

JSTOR is a not-for-profit service that helps scholars, researchers, and students discover, use, and build upon a wide range of content in a trusted digital archive. We use information technology and tools to increase productivity and facilitate new forms of scholarship. For more information about JSTOR, please contact support@jstor.org. 


\title{
FACTORS AFFECTING INTERANNUAL MOVEMENTS OF SNOWY PLOVERS
}

\author{
Peter W. C. PAton ${ }^{1,3}$ AND Thomas C. EdWARds, JR. ${ }^{1,2}$ \\ ${ }^{1}$ Department of Fisheries and Wildlife and ${ }^{2}$ National Biological Service, \\ Utah Cooperative Fisheries and Wildlife Research Unit, \\ Utah State University, Logan, Utah 84322, USA
}

\begin{abstract}
We studied the interannual movements of 361 individually color-banded adult Snowy Plovers (Charadrius alexandrinus nivosus) at Great Salt Lake, Utah from 1990 to 1993. In northern Utah, Snowy Plovers nested in a dynamic environment; suitable breeding habitat declined by $50 \%$ at two study areas in four years. Male Snowy Plovers were more site faithful than females; $40 \%$ of males exhibited fidelity compared with $26 \%$ of females $(P<0.01)$. However, as the amount of available suitable nesting habitat declined, male site fidelity diminished, whereas female fidelity remained relatively constant. We found strong evidence that female site fidelity was affected by nesting success in the previous year. Females that nested unsuccessfully were less likely than successful females to exhibit site fidelity the following year; males did not exhibit this nest-success bias. In addition, unsuccessful females breeding at sites with high densities of nests tended to disperse the following year, whereas male site fidelity did not appear to be affected by either a study site's overall nesting success the previous year or a study site's nest density the previous year. Female avoidance of areas with high densities of nests may be an antipredator strategy. Snowy Plovers in northern Utah have biparental incubation duties, but only males care for broods. Familiarity with brood-rearing areas was one plausible explanation for male-biased fidelity. However, we could not eliminate an alternative hypothesis that both focal study sites represented scarce breeding areas due to the presence of freshwater, and male Snowy Plovers preferred to use the same areas rather than disperse. We propose that more landscape-level studies are needed to address questions concerning local and regional movement patterns. Received 22 August 1994, accepted 27 January 1995.
\end{abstract}

MIGRATORY BIRDS face a dilemma when returning to their breeding grounds: Should an individual breed at the same site as the previous year, or disperse to a new area? Individuals faithful to their previous breeding grounds presumably have some knowledge concerning the distribution of essential resources, predation risks, and potential mates (Shields 1982, Oring and Lank 1984, Gratto et al. 1985, Wiens and Cuthbert 1988). However, dispersing individuals have the opportunity to find a new territory or another mate, either of which could change reproductive output (Ollason and Dunnet 1978, Cuthbert 1988). Birds typically exhibit female-biased natal and breeding dispersal (i.e. females disperse farther and more often; Greenwood 1980, Greenwood and Harvey 1982; but see Oring and Lank 1984). The proximate and ultimate causes for sex-biased dispersal are still

\footnotetext{
${ }^{3}$ Present address: Department of Natural Resources Science, University of Rhode Island, Kingston, Rhode Island 02881, USA. E-mail: ppaton@uriacc.uri.edu
}

under debate (Bollinger and Gavin 1989, Anderson et al. 1992).

Previous studies of avian populations have found a strong tendency for individuals to exhibit a higher degree of site fidelity after a successful nesting attempt than after an unsuccessful one (Greig-Smith 1982, Oring and Lank 1982, Gratto et al. 1985, Cuthbert 1988, Pärt and Gustafsson 1989, Hepp and Kennamer 1993; but see Haig and Oring 1988a, Schamel and Tracy 1991). In addition, older birds are often more likely to return to the same area than younger birds (Oring et al. 1983, Oring and Lank 1984, Thompson and Hale 1989, Montalvo and Potti 1992). Site quality, measured in terms of the number of young fledged from an area, also can affect return rates, with greater return rates to higher-quality sites regardless of an individual's nesting success the previous year (Bollinger and Gavin 1989, Montalvo and Potti 1992).

Charadrius plovers provide an excellent opportunity to investigate proximate causes of dispersal. Birds in this genus often forage on unvegetated substrates (making it easy to see 
bands), they nest at discrete sites (Page et al. 1991), several mating systems are known (Haig and Oring 1988a, Lessells 1984, Warriner et al. 1986), and large interannual dispersal distances have been documented (Haig and Oring 1988b, Székely and Lessells 1993, Stenzel et al. 1994). Adult Piping Plovers (C. melodus) exhibit varying degrees of site fidelity (25-69\% of birds return to previous nesting areas), are almost exclusively monogamous, and have biparental care of young (Haig and Oring 1988a, b). Haig and Oring (1988b) postulated that in areas with limited suitable nesting habitat, Piping Plovers should show a high degree of site fidelity, whereas in areas with many potential breeding sites, individuals should show less site fidelity. Movements are extreme in the North American Snowy Plover (C. alexandrinus nivosus); median dispersal distance is $175 \mathrm{~km}$ between breeding seasons (maximum 1,140 km; Stenzel et al. 1994). Mated pairs of the conspecific European Kentish Plover (C. a. alexandrinus) move an average of $12 \mathrm{~km}$ between years (Székely and Lessells 1993). These two subspecies exhibit both monogamy and sequential polyandry within the same populations (Rittinghaus 1956, Boyd 1972, Lessells 1984, Warriner et al. 1986, Székely and Lessells 1993, Stenzel et al. 1994). No study of the genus Charadrius has specifically investigated the effect of changes in the amount of suitable nesting habitat on movements. Stenzel et al. (1994) investigated the relationship between prior nesting success and movements of individual Snowy Plovers breeding in coastal California and found no significant relationship for either sex. Therefore, the reasons for the relatively large dispersal distances found within this genus remain unresolved.

We investigated the effects of three factors on movements of adult Snowy Plovers in northern Utah by evaluating: (1) the overall nest density of a study site; (2) the overall hatching success of a study site; and (3) an individual's nesting success the previous year. We were unable to quantify fledging rates at our focal sites because broods were highly cryptic and often crossed study area boundaries before fledging. Therefore, we could not quantify the relationship between site quality (Bollinger and Gavin 1989) and plover movements. We first describe interannual movements of Snowy Plovers at the Great Salt Lake in Utah. We then quantify changes in the abundance of potential nesting habitat at two focal study sites. Finally, we in- vestigate the relationships among nest density, nest success, and movements and also evaluate site fidelity relative to an individual's prior nesting success.

\section{STUDY AREA AND METHODS}

Great Salt Lake, Utah, has a mean depth of $4.3 \mathrm{~m}$ at typical lake levels and has no outlet (Arnow and Stephens 1990). Lake levels, therefore, oscillate with precipitation levels. From 1983 to 1987, the lake rose $3.7 \mathrm{~m}$, inundating approximately $2,100 \mathrm{~km}^{2}$ of marsh and upland habitat (Foote 1991). Thousands of hectares were denuded as the lake receded from 1988 to 1993, which created large expanses of suitable nesting habitat for Snowy Plovers. These barren areas eventually were revegetated by salt-tolerant species within the Chenopodiaceae, including greasewood (Sarcobatus vermiculatus), iodine bush (Allenrolfea occidentalis), seepweed (Sueda spp.), summer cypress (Kochia scoparia), bassi (Bassi hyssopifolia), and pickleweed (Salicornia europaea). In addition, emergent vegetation increased over the course of the study, including alkali bulrush (Scirpus maritmus), cattail (Typha spp.), and phragmites (Phragmites australis; see also Foote 1991).

Adult Snowy Plovers were individually colorbanded and monitored at eight primary study sites at Great Salt Lake from 1990 to 1993: (1) Locomotive Springs Waterfowl Management Area (WMA; $41^{\circ} 41^{\prime} \mathrm{N}$, $112^{\circ} 55^{\prime} \mathrm{W}$ [7 male and 9 female plovers]); (2) Harold Crane WMA $\left(41^{\circ} 20^{\prime} \mathrm{N}, 112^{\circ} 08^{\prime} \mathrm{W}\right.$ [ 16 males and 21 females]); (3) the West Warren area of Harold Crane WMA ( $41^{\circ} 18^{\prime} \mathrm{N}, 112^{\circ} 08^{\prime} \mathrm{W}$ [ 2 males and 8 females]); (4) northwestern corner of Ogden Bay WMA $\left(41^{\circ} 14^{\prime} \mathrm{N}\right.$, $112^{\circ} 14^{\prime} \mathrm{W}$ [10 males and 15 females]); (5) Howard Slough WMA $\left(41^{\circ} 09^{\prime} \mathrm{N}, 112^{\circ} 09^{\prime} \mathrm{W}\right.$ [60 males and 69 females]), (6) West Layton Marsh $\left(41^{\circ} 02^{\prime} \mathrm{N}, 112^{\circ} 05^{\prime} \mathrm{W}\right.$ [59 males and 68 females]), (7) Farmington Bay WMA $\left(40^{\circ} 55^{\prime} \mathrm{N}, 111^{\circ} 55^{\prime} \mathrm{W}\right.$ [ 3 males and 2 females]); and (8) $2 \mathrm{~km}$ northeast of Saltair Beach $\left(40^{\circ} 46^{\prime} \mathrm{N}, 112^{\circ} 08^{\prime} \mathrm{W}\right.$ [ 5 males and 7 females]). Fieldwork was centered at two "focal study sites" that were $10 \mathrm{~km}$ apart: Howard Slough WMA, a diked, managed marsh; and West Layton Marsh, an undiked, unregulated marsh (Fig. 1). Focal sites were surveyed two to three times per week. In 1990, one observer surveyed Howard Slough from 19 May to 31 August and West Layton Marsh from 13 June to 31 August. From 1991 to 1993, focal sites were surveyed by two observers from 1 April to 31 August. The other six sites were surveyed one to four times per month.

Annual changes in the distribution of Snowy Plover nesting habitat at the focal sites were quantified by taking black-and-white aerial photographs (photo scale: $1 \mathrm{~cm}=100 \mathrm{~m}$ ) in mid-June from 1990 through 1993. Potential nesting-habitat patches were delineated based on two criteria: (1) a total area greater than 0.1 ha in size; and (2) live or dead vegetation 


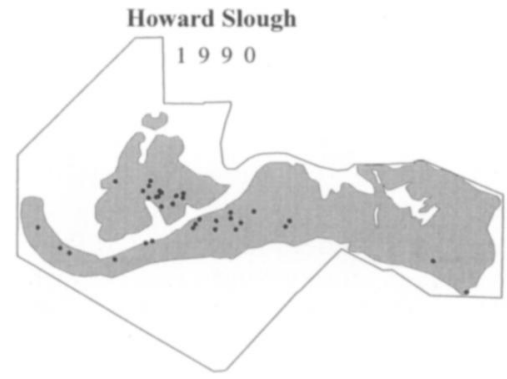

West Layton Marsh

1990
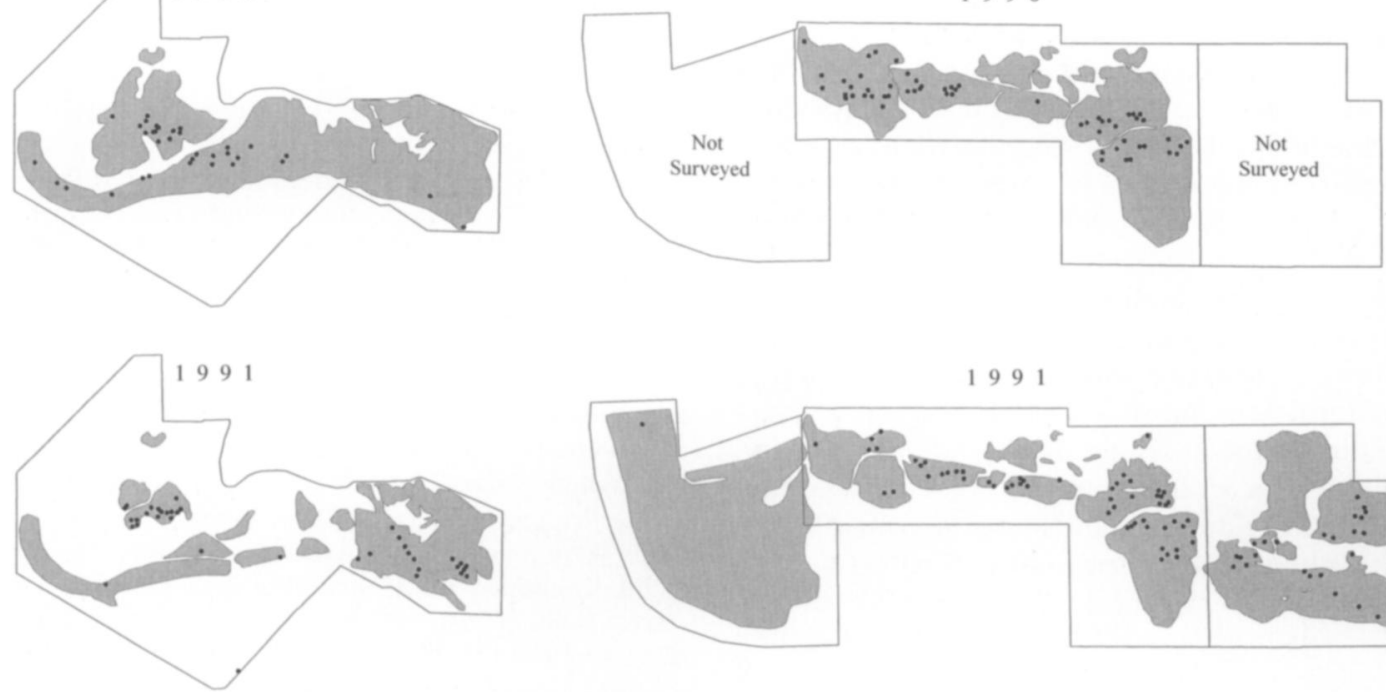

1991

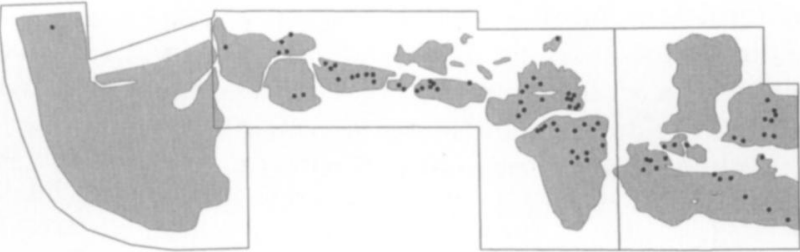

1992

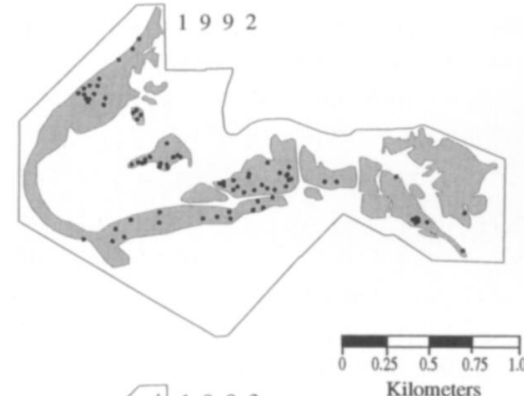

1992
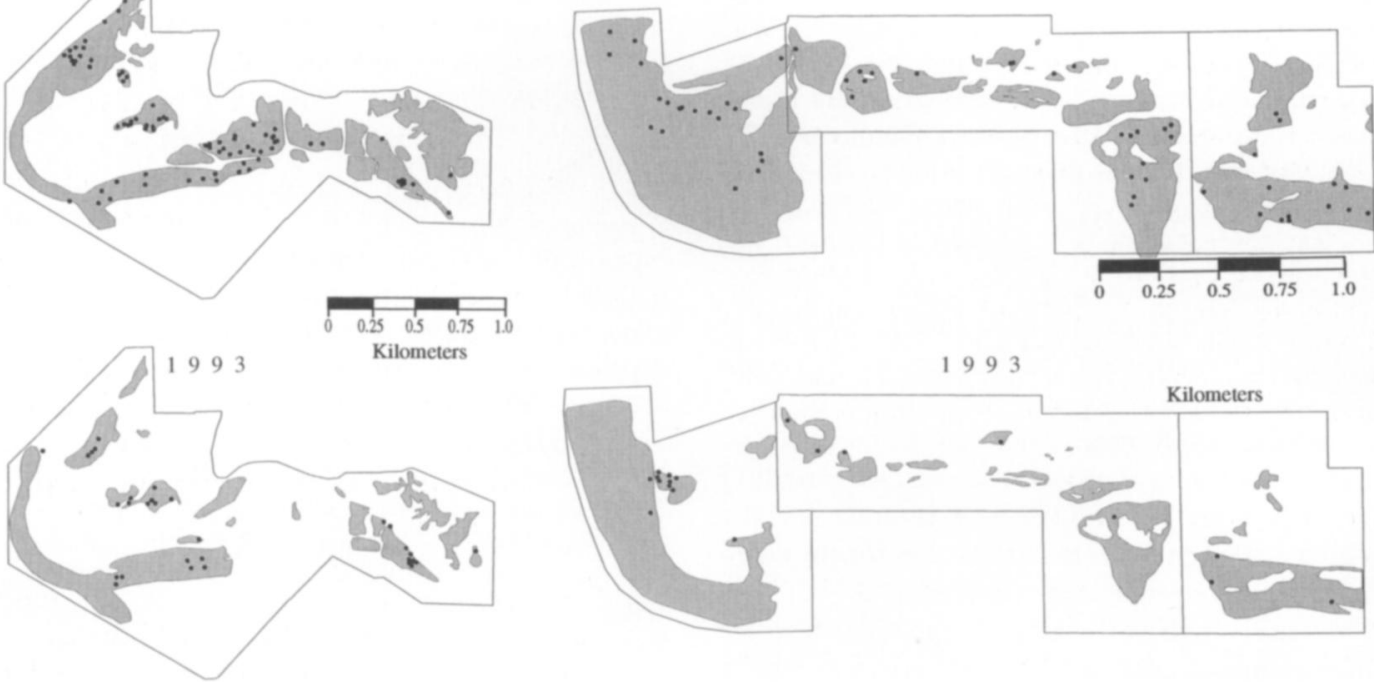

1993

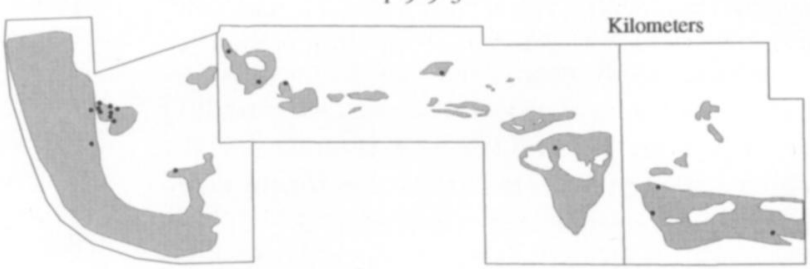

FIG. 1. Interannual differences in the distribution of Snowy Plover nests (dots) and potential nesting habitat (dark patches) at two focal study sites at Great Salt Lake, 1990 to 1993.

must account for less than $25 \%$ of the total ground within a habitat patch (Wilson-Jacobs and Meslow 1984, Page et al. 1985, Paton and Edwards 1990). Barren areas that consisted of soft mud (e.g. adjacent to lake shoreline, or deltas formed where ditches met lake) were not classified as potential nesting habitat because Snowy Plovers nest only on dry substrates (P. Paton unpubl. data). Potential nesting habitat was then digitized from the aerial photographs and analyzed using ARC/INFO software (Environmental Systems Research Institute, Redlands, California).
Eggs were floated to determine expected hatching dates using methods described in Westerkov (1950). We assumed a four-day egg laying period and a 27day incubation period (Page et al. 1985, Warriner et al. 1986). Nests in which at least one egg hatched were defined as successful; nests that were empty prior to expected hatching dates were considered to have failed (Page et al. 1983, 1985). Most nest predators were mammals (Paton 1995).

We determined the density of plover nests only at the two focal sites because the other sites were not 
visited frequently enough to insure that most nests were found. We assumed that few nests were missed during nest searches at the focal sites. At Howard Slough and West Layton Marsh in 1992 and 1993, only 3 of 188 nests had eggs greater than 21 days old or chicks in the scrape when they were initially discovered, suggesting that most nests were found during the early stages of incubation. Nest density was calculated at each focal study site using three estimators (modified from Kantrud and Stewart 1984): (1) crude density, defined as the total number of nests found in one breeding season/total area surveyed; (2) ecological density, defined as the total number of nests found in one breeding season/amount of potential habitat available; and (3) daily ecological density, defined as the maximum number of nests active on any one day/ amount of potential habitat available.

Incubating adults were captured with a chickenwire drop trap in 1990 (Paton and Edwards 1990) and a circular funnel trap from 1991 to 1993 (Lessells 1984). In addition, breeding and nonbreeding plovers were trapped 0.1 to $1.0 \mathrm{~km}$ from nesting areas by herding birds into two mist nets, which were staked together to form a $V$. The capture technique used did not significantly affect resighting probabilities for females, although there was a nonsignificant trend for males captured while incubating to be resighted at a higher rate than males captured in nets (see Paton 1995). The gender of adults was determined using plumage characteristics (Page et al. 1983, Warriner et al. 1986). Snowy Plovers were individually marked with three unicolored plastic bands (A. C. Hughes Ltd., Middlesex, England; band size XCL) and a U.S. Fish and Wildlife Service metal band (special size 1AA). Two bands were placed on each tarsometatarsus. Colored plastic tape, available from automotive stores, was then soldered over the plastic and metal bands. The tape minimized band loss, as only three birds each lost one plastic band during the study.

Movements of color-banded plovers were determined to the nearest $30 \mathrm{~m}$ by plotting daily observations of banded birds onto field maps of each study site $(1 \mathrm{~cm}=100 \mathrm{~m})$. Universal Transverse Mercator (UTM) coordinates were determined for each observation and used for distance calculations. Nest locations at the focal study sites were accurate to within $10 \mathrm{~m}$ using a satellite-based global positioning system (Magellan Systems Corporation, Monrovia, California) and re-verified by manually plotting nest locations onto high-resolution orthophotoquads of the focal study sites $(1 \mathrm{~cm}=25 \mathrm{~m})$. Nearest-neighbor distances within active plover colonies were determined with a measuring tape to the nearest $0.5 \mathrm{~m}$.

Interannual movements for individual Snowy Plovers were based on the arithmetic mean for all UTM coordinates within a year, and compared with the arithmetic mean for UTM coordinates from the previous year. Intersexual differences in interannual movements (both annual home ranges and nest sites) were compared with a Mann-Whitney $U$-test. We classified plovers as being site faithful if they returned to the same study site. We evaluated the relationships between an individual's site fidelity and: (1) studysite nest density, (2) study-site nesting success, and (3) nesting success for specific individuals using a loglinear model with a backward-selection approach (Agresti 1990). Because some cell counts equaled zero, we added 0.5 to each cell before calculating likelihood-ratio chi square statistics (Agresti 1990). An alpha level of less than 0.05 was considered significant.

\section{RESULTS}

Interannual movements. - Males banded at the focal study sites became less site faithful over the course of the study (i.e. $56 \%$ in $1991,44.5 \%$ in 1992, and $35.5 \%$ in $1993 ; G=10.8, \mathrm{df}=4, P$ $=0.03$; Table 1), whereas females returned at a relatively constant rate $(33.3 \%, 29.7 \%$, and $28.9 \%$ from 1991 to 1993, respectively; $G=6.7$, df $=$ $4, P=0.15)$. When data from all study sites were pooled, we found no annual variation in site fidelity for either sex (males: $G=3.9, \mathrm{df}=4, P$ $=0.41$; females: $G=5.9, \mathrm{df}=4, P=0.21$; Table 1). Pooled data from all study sites suggested that males were more site faithful than females; $39.7 \%$ of males returned to the same site compared with $25.5 \%$ of females $(G=9.5, \mathrm{df}=2, P$ $=0.009$; Table 1). In addition, adult males usually were resighted consistently year after year; only $11.3 \%$ of 71 adult males banded at the focal study sites in 1990 or 1991 were missing for one year and subsequently resighted, compared with $24.7 \%$ of 73 females. This gender bias in resighting consistency was close to statistical significance $(G=3.7, \mathrm{df}=1, P=0.054)$.

Interannual movements of color-banded plovers around Great Salt Lake were considerable (Table 2). Birds moved readily between the two focal sites (which were $10 \mathrm{~km}$ apart); approximately $10 \%$ of the birds banded at Howard Slough or West Layton Marsh visited both of these sites. Birds dispersed as far as $104 \mathrm{~km}$ (e.g. from Locomotive Springs to West Layton Marsh). The geographic center of adult female home ranges moved about $1.5 \mathrm{~km}$ between years (median $=1.64 \mathrm{~km}, 25-75 \%$ quantiles $=0.59-$ $11.99 \mathrm{~km}$, range $=0.05-101.4 \mathrm{~km}, n=95)$, whereas males moved about $1 \mathrm{~km}$ (median = $1.11 \mathrm{~km}, 25-75 \%$ quantiles $=0.54-7.21$, range $=$ 0.1-69.7 km, $n=94$ ). However, interannual movements were not significantly different between the sexes (Mann-Whitney $U$-test, $P=$ 
TABLE 1. Intersexual differences in site fidelity of individually color-banded Snowy Plovers at Great Salt Lake, Utah. Birds were subsequently observed at the same study site (site faithful), seen at another study site (moved), or not resighted. Data from just the two focal study sites (Howard Slough and West Layton Marsh) and all eight study sites are presented.

\begin{tabular}{|c|c|c|c|c|c|c|c|}
\hline \multirow[b]{2}{*}{$\begin{array}{c}\text { Resighting } \\
\text { year }\end{array}$} & \multicolumn{3}{|c|}{ Number of males } & \multicolumn{3}{|c|}{ Number of females } & \multirow[b]{2}{*}{$G^{\mathbf{a}}$} \\
\hline & $\begin{array}{c}\text { Site } \\
\text { faithful }\end{array}$ & Moved & $\begin{array}{l}\text { Not } \\
\text { resighted }\end{array}$ & $\begin{array}{c}\text { Site } \\
\text { faithful }\end{array}$ & Moved & $\begin{array}{c}\text { Not } \\
\text { resighted }\end{array}$ & \\
\hline \multicolumn{8}{|c|}{ Plovers banded only at focal study sites } \\
\hline 1991 & 14 & 7 & 4 & 12 & 13 & 11 & 3.4 \\
\hline 1992 & 33 & 1 & 31 & 22 & 16 & 36 & 3.9 \\
\hline 1993 & 33 & 14 & 46 & 30 & 19 & 55 & 1.0 \\
\hline \multicolumn{8}{|c|}{ Plovers banded at all study sites } \\
\hline 1991 & 15 & 9 & 10 & 12 & 15 & 16 & 2.2 \\
\hline 1992 & 34 & 14 & 41 & 24 & 21 & 53 & 4.2 \\
\hline 1993 & 40 & 10 & 51 & 35 & 26 & 76 & 3.4 \\
\hline All years & 89 & 33 & 102 & 71 & 62 & 145 & $9.5^{* *}$ \\
\hline
\end{tabular}

- Log-likelihood-ratio test between sexes; ${ }^{*}, P<0.001$; all others not significant.

0.21 ). We documented interannual movements between nest sites of about $1 \mathrm{~km}$ for females (median $=0.90 \mathrm{~km}$, range $=0.06-23.7 \mathrm{~km}, n=$ 12) and $0.6 \mathrm{~km}$ for males (median $=0.58 \mathrm{~km}$, range $=0.06-12.7 \mathrm{~km}, n=10)$; the difference was not significant (Mann-Whitney $U$-test, $P=$ 0.97).

Habitat changes. - Snowy Plovers at Howard Slough and West Layton Marsh typically nested in a limited number of habitat patches; the size and location of these patches varied annually (Fig. 1). The number of synchronous nests within $100 \mathrm{~m}$ of each other varied from three to nine, with nearest-neighbor distances averaging 36.2 $\pm \mathrm{SD}$ of $20.0 \mathrm{~m}$ (range $=7.5-90 \mathrm{~m}, n=79$ nests).

The distribution and availability of suitable nesting habitat at focal study sites changed substantially during the study period, primarily due to reestablishment of vegetation. At Howard Slough, we surveyed 349 ha annually. The amount of suitable nesting habitat declined $56 \%$ over four years (Table 3, Fig. 1), with the ex- ception of 1992, when potential nesting habitat increased due to drawdowns (P. Paton unpubl. data). At West Layton Marsh, we increased study area boundaries from 171 ha in 1990 to 400 ha in 1991 to incorporate more potential nesting habitat (Fig. 1). In 1990, 43.9\% of West Layton Marsh was classified as potential nesting habitat, whereas by 1993 , only $22.5 \%$ of the marsh was suitable for nesting (Table 3, Fig. 1).

Although both focal study sites experienced significant declines in the amount of suitable nesting habitat, there was not a concomitant reduction in the number of Snowy Plovers nesting at Howard Slough. At Howard Slough, estimated nest density and the total number of nests increased from 1990 to 1992; nest density and the total number of nests decreased only in 1993 (Table 4). In contrast, estimated nest density and the number of nests declined at West Layton Marsh during the study period (Table 4).

We found no significant relationship be-

TABLE 2. Movements of individually color-banded adult Snowy Plovers around Great Salt Lake, Utah.

\begin{tabular}{|c|c|c|c|c|c|c|c|c|c|}
\hline \multirow[b]{2}{*}{ Banding location } & \multirow{2}{*}{$\begin{array}{c}\text { No. } \\
\text { birds } \\
\text { banded }\end{array}$} & \multicolumn{7}{|c|}{ Resighting location in subsequent years } & \multirow[b]{2}{*}{ LS } \\
\hline & & SB & FB & WL & HS & $\mathrm{HC}$ & NO & WW & \\
\hline Saltair Beach (SB) & 12 & 4 & & 1 & & & & & \\
\hline Farmington Bay (FB) & 5 & 1 & & 1 & & & & 1 & \\
\hline West Layton Marsh (WL) & 127 & 6 & 1 & 66 & 13 & 2 & & & 1 \\
\hline Howard Slough (HS) & 129 & 4 & & 14 & 58 & & 2 & & \\
\hline Harold Crane (HC) & 37 & 1 & & & 5 & 1 & & 1 & 1 \\
\hline North Ogden Bay (NO) & 25 & & & 2 & 1 & & 2 & & 1 \\
\hline West Warren (WW) & 10 & 1 & & 1 & & & & 7 & \\
\hline Locomotive Springs (LS) & 16 & & & 3 & & & & & 1 \\
\hline
\end{tabular}


TABLE 3. Interannual differences in the total amount (ha) and patch size (ha) of potential Snowy Plover nesting habitat at two study sites at Great Salt Lake, Utah, from 1990 to 1993.

\begin{tabular}{cccccc}
\hline \hline & \multicolumn{2}{c}{ Howard Slough } & & \multicolumn{2}{c}{ West Layton Marsh } \\
\cline { 2 - 3 } \cline { 5 - 6 } & Total area & $\begin{array}{c}\text { Median patch size } \\
(\text { range, } n)\end{array}$ & & $\begin{array}{c}\text { Total } \\
\text { area }\end{array}$ & $\begin{array}{c}\text { Median patch size } \\
\text { (range, } n)\end{array}$ \\
\hline 1990 & 147 & $31.7(1.1-114.1,3)$ & & 75 & $2.4(0.4-21.9,10)$ \\
1991 & 85 & $2.6(0.9-43.5,11)$ & & 188 & $3.8(0.1-78.2,19)$ \\
1992 & 102 & $2.4(0.2-45.0,15)$ & & 156 & $0.5(0.1-81.3,22)$ \\
1993 & 64 & $1.5(0.2-32.2,18)$ & & 90 & $0.6(0.1-46.7,22)$ \\
\hline
\end{tabular}

tween site fidelity and a study site's nest density the previous year for either $\operatorname{sex}(G=0.33$, df $=$ $1, P=0.56$; Table 5). We further explored the effects of nest density on adult site fidelity by simultaneously comparing return rates of adults to both their nesting success the previous year and overall study site ecological nest density the previous year. At high nest densities $(>0.5$ nests/ha), successful females were more likely to return to the same study site than were unsuccessful females $(P=0.003)$. However, when nest densities were low ( $\leq 0.5$ nests $/$ ha) the previous year, an individual's prior nesting success did not affect site fidelity $(P=0.11)$. There also was no significant relationship between the number of site-faithful adults and overall nesting success for a given study site $(G=0.02, \mathrm{df}$ $=1, P=0.88$ ).

Nesting success in the preceding year did not affect the probability that males returned to the same focal study site in the following year $(89.7 \%$ of 39 successful males returned compared with $86.7 \%$ of 15 unsuccessful males; $G=0.101, \mathrm{df}=$ $1, P=0.75$; Table 6). However, nesting success in the previous year did affect female site fidelity. Of the females that were resighted, $90.6 \%$ of 32 that nested successfully in the previous year returned to the same focal study site, whereas only $50 \%$ of 20 unsuccessful females returned to the same site $(G=13.58, \mathrm{df}=1, P$ $<0.001)$. Site fidelity was similar between suc- cessful males and females $(G=0.015, \mathrm{df}=1, P$ $=0.901$ ), whereas unsuccessful females were less site faithful than were unsuccessful males $(G=6.98, \mathrm{df}=1, P=0.008)$.

\section{Discussion}

Our study revealed at least four movement patterns for Snowy Plovers at Great Salt Lake. First, adult males were consistently site faithful, with $36 \%$ to $56 \%$ returning annually to the same focal study site. We found that nesting success in the preceding year did not appear to affect movements of males, a result also documented by Stenzel et al. (1994) in California. We also found no significant relationship between male site fidelity and: (1) density of nests at the focal study sites in the previous year or (2) a study site's nest success in the previous year. However, there was an indication that when the amount of suitable habitat declined at the focal study sites, the percentage of males that were site faithful declined as well (Table 1). In contrast, females returned at a relatively constant rate from year to year.

Second, females were less site faithful than males (i.e. only $26 \%$ of females returned to the same site between years compared with $40 \%$ of males; Table 1). Previous research has shown that survival estimates for Snowy Plovers at Great Salt Lake are similar for both sexes, sur-

TABLE 4. Interannual differences in Snowy Plover nest densities using three estimators at two study sites at Great Salt Lake, Utah from 1990 to 1993.

\begin{tabular}{ccccccccc}
\hline \hline & \multicolumn{3}{c}{ Howard Slough } & & \multicolumn{3}{c}{ West Layton Marsh } \\
\cline { 2 - 3 } Year & Crude $^{\mathrm{a}}$ & Ecological $^{\mathrm{b}}$ & Daily $^{\mathrm{c}}$ & & Crude & Ecological & Daily \\
\hline 1990 & 0.097 & 0.232 & 0.054 & & 0.339 & 0.773 & 0.493 \\
1991 & 0.106 & 0.435 & 0.129 & & 0.208 & 0.441 & 0.112 \\
1992 & 0.232 & 0.833 & 0.275 & & 0.140 & 0.359 & 0.154 \\
1993 & 0.089 & 0.484 & 0.141 & & 0.050 & 0.222 & 0.078 \\
\hline
\end{tabular}

- Crude: cumulative number of nests active in one year/total area surveyed; nests/ha.

b Ecological: cumulative number of nests active in one year/total area of potential nesting habitat; nests/ha.

'Daily: maximum number of nests active on one day within a breeding season/total area of potential nesting habitat; nests/ha. 
TABLE 5. Total number of banded adult Snowy Plovers that were resighted at the same study site or seen elsewhere in relationship to overall study-site nest densities the previous year.

\begin{tabular}{ccc}
\hline \hline & \multicolumn{2}{c}{$\begin{array}{c}\text { Density of nests the } \\
\text { previous year }\end{array}$} \\
\cline { 2 - 3 } Sex & $\begin{array}{c}\leq 0.5 \\
\text { nests/ha }\end{array}$ & $\begin{array}{c}>0.5 \\
\text { nests } / \text { ha }\end{array}$ \\
\hline \multicolumn{4}{c}{ Site faithful } & \\
Male & 39 & 43 \\
Female & 36 & 26 \\
Resighted at another study site & \\
Male & 4 & 8 \\
Female & 8 & 6 \\
\hline
\end{tabular}

- Ecological density: cumulative number of nests active in one year/ total area (ha) of potential nesting habitat; nests/ha.

vival estimates appear to vary annually, and resighting probabilities are significantly lower for females than males (Paton 1994). Twentythree percent of females during this study were not resighted in one or more years and then subsequently resighted, while only $11 \%$ of banded males were missing in at least one year. This pattern is similar to Stenzel et al. (1994), who found that approximately $50 \%$ of females were absent from their study sites in western North America for part or all of a breeding season, while only $25 \%$ of the males were not consistently resighted.

Third, female movements were affected by an individual's nesting success in the previous year. Successful females were 11.6 times (95\% confidence interval $=2.7-49.7$ ) more likely than unsuccessful females to return to the same area (Table 6). This was the first time this relationship has been reported in Snowy Plovers (see Stenzel et al. 1994). Reasons for the discrepancy between our findings and those of the California study are unclear. One possible explanation is the relatively poor annual nesting success during our study, which was as low as 5\% (Paton 1995). In contrast, nesting success exceeded $60 \%$ in coastal California during the early 1980s (Warriner et al. 1986). Females nesting at Great Salt Lake may be under greater predation pressure and, therefore, may disperse more readily following failed nesting attempts.

Finally, unsuccessful females nesting at sites with relatively high densities of nests were more likely to move elsewhere in subsequent years compared with females that nested at sites with low densities of nests. Female Snowy Plovers in Utah moved to areas with lower nest densities following nest failure. This corresponds with the results of Page et al. (1983), who showed in a series of experiments that plovers probably select areas with low nest densities as an antipredator strategy. Therefore, sites with high nest densities are possibly low-quality breeding sites for Snowy Plovers (see Van Horne 1983, Vickery et al. 1992). Unfortunately, we were not able to accurately determine fledging rates at any of our study areas; therefore, we could not quantify the relationship between site quality and nest density.

One obvious question is why are male Snowy Plovers more site faithful than females? Parental care appears to play an important role in determining gender bias in adult site-fidelity patterns (Greenwood 1980, Greenwood and Harvey 1982, Oring and Lank 1984). Oring and Lank (1984) reviewed site-fidelity patterns of adult sandpipers (family Scolopacidae) and found that monogamous species (i.e. ones with biparental care of young and both sexes territorial) had the highest degree of site fidelity. In contrast, species that were nonterritorial and exhibited uniparental care were less site faithful (e.g. Red Phalaropes [Phalaropus fulicaria]; Schamel and Tracy 1977, 1991). Lessells (1985) argued that parental care played an important role in the evolution of female-biased philopatry in ducks (Anatidae), one of the few avian taxa in which females are more site faithful than males (see also Anderson et al. 1992). Female ducks are responsible for rearing the brood, and individuals familiar with a site may have a se-

TABLE 6. Site fidelity (\%) of adult Snowy Plovers at Great Salt Lake relative to an individual's nesting success the previous year.

\begin{tabular}{|c|c|c|c|c|c|c|}
\hline \multirow[b]{2}{*}{ Sex } & \multicolumn{3}{|c|}{ Nest successful } & \multicolumn{3}{|c|}{ Nest unsuccessful } \\
\hline & $\begin{array}{c}\text { Site } \\
\text { faithful }\end{array}$ & $\begin{array}{l}\text { Resighted } \\
\text { elsewhere }\end{array}$ & $n$ & $\begin{array}{c}\text { Site } \\
\text { faithful }\end{array}$ & $\begin{array}{l}\text { Resighted } \\
\text { elsewhere }\end{array}$ & $n$ \\
\hline Female & 90.6 & 9.4 & 32 & 50.0 & 50.0 & 20 \\
\hline Male & 89.7 & 10.3 & 39 & 86.7 & 13.3 & 15 \\
\hline
\end{tabular}


lective advantage over inexperienced individuals (Shields 1982).

A similar hypothesis may explain male site fidelity in Snowy Plovers. Both sexes share incubation duties, but usually only the male parent remains with the brood (Lessells 1984, Warriner et al. 1986, Paton 1995; but see Boyd 1972). If familiarity with brood-rearing areas provides a selective advantage to the parent(s) responsible for brood care, this might explain the gender bias that we observed. Greenwood's (1980) arguments about the importance of resourcedefense are not applicable to Snowy Plovers in Utah. Male Snowy Plovers exhibit little resource defense, and they forage in flocks at sites away from nesting areas when they are not incubating. Intraspecific disputes generally occur only near active nests (Warriner et al. 1985, Paton 1995).

Male Snowy Plovers arrive on their breeding grounds at Great Salt Lake about one week before females (Paton 1995), and this species has a male-biased sex ratio (Warriner et al 1986). This suggests there is strong intrasexual competition for mates, and site-faithful males may have an advantage in acquiring a mate. We have no data to test this hypothesis, but it is an alternative that should be examined experimentally in the field in the future.

Another alternative explanation for male-biased fidelity among Snowy Plovers in Utah is that the focal study sites were exceptional areas compared with many other potential breeding sites around Great Salt Lake (i.e. nest densities were probably at least two to three times greater at focal study sites; Paton and Edwards 1990, P. Paton unpubl. data). Freshwater is a limited resource at Great Salt Lake, and one that is readily available at both Howard Slough and West Layton Marsh. Freshwater is critical to nesting plovers because chicks cannot tolerate the high salt concentrations found in hypersaline lakes such as Great Salt Lake (Purdue and Haines 1977). Therefore, males may return to the same sites to take advantage of this limited resource. Bollinger and Gavin (1989) found that Bobolinks (Dolichonyx oryzivorus) returned consistently to high-quality sites, regardless of an individual's nesting success the preceding year, while birds were less likely to return to relatively low-quality sites following nest failure. Snowy Plovers can live for 10 to 15 years (G. Page pers. comm.); therefore, males may continue to return to the same site in "anticipation" of a productive breeding season.
Finally, this study and work by Stenzel et al. (1994) point out the importance of working at both local and landscape levels to address questions of dispersal in species such as the Snowy Plover. Our studies have shown that plovers are capable of moving great distances within and between years. Such movement may be an adaptation to the highly ephemeral saline lakes throughout western North America. Birds appear to be constantly exploring the region searching for potential nesting areas. As nesting habitat declines at a specific site, males remain site faithful while females are more apt to disperse to a new site. It is only by working at many sites scattered over the landscape that these types of movements are documented.

\section{ACKNOWLEDGMENTS}

We thank our field assistants Jack Dalton, Jennifer Levy, and Craig Kneedy. Randy Radant, Frank Howe, Don Paul, Val Backman, and Justin Dolling, all with Utah Division of Wildlife Resources, helped with logistical support. Financial support was provided by Utah Division of Wildlife Resources, Native Wildlife Section. The manuscript was improved by helpful comments from John Kadlec, Kate Lessells, Frank Messina, Lewis Oring, Mark Ritchie, and Kim Sullivan.

\section{LITERATURE CITED}

Agresti, A. 1990. Categorical data analysis. Wiley and Sons, New York.

ANDERSON, M. G., J. M. RHYMER, AND F. C. ROHWER. 1992. Philopatry, dispersal, and the genetic structure of waterfowl populations. Pages 365395 in Ecology and management of breeding waterfowl (B. D. J. Batt, A. D. Afton, M. G. Anderson, C. D. Ankney, D. H. Johnson, J. A. Kadlec, and G. L. Krapu, Eds.). University of Minnesota Press, Minneapolis.

ARNOW, T., AND D. STEPHENS. 1990. Hydrological characteristics of the Great Salt Lake, Utah: 18471986. United States Geological Survey, Watersupply Paper 2332, Denver, Colorado.

BOLlinger, E. K., AND T. A. GAvIN. 1989. The effects of site quality on breeding-site fidelity in Bobolinks. Auk 106:584-594.

BoYD, R. L. 1972. Breeding biology of the Snowy Plover at Cheyenne Bottoms Waterfowl Management Area, Barton County, Kansas. M.S. thesis, Kansas State Teachers College, Emporia.

CUTHBERT, F. J. 1988. Reproductive success and colony-site tenacity in Caspian Terns. Auk 105:339344.

Foote, A. L. 1991. Great Salt Lake flooding: Destruc- 
tion and reestablishment of wetland vegetation. Ph.D. dissertation, Utah State University, Logan.

$\rightarrow$ Gratto, C. L., R. I. G. MorRISON, AND F. COOKE. 1985 Philopatry, site tenacity, and mate fidelity in the Semipalmated Sandpiper. Auk 102:16-24.

$\rightarrow$ GreENWOOD, P. J. 1980. Mating systems, philopatry and dispersal in birds and mammals. Animal Behaviour 28:1140-1162.

GREENWOOD, P. J., AND P. H. HARVEY. 1982. The natal and breeding dispersal of birds. Annual Review of Ecology and Systematics 13:1-21.

GreIG-SMITH, P. W. 1982. Dispersal between nestsites by Stonechats Saxicola torquata in relation to previous breeding success. Ornis Scandinavica 13:232-238.

$\rightarrow$ HaIG, S. M., AND L. W. ORING. 1988a. Mate, site, and territory fidelity in Piping Plovers. Auk 105:268277.

$\rightarrow$ HaIG, S. M., AND L. W. ORING. 1988b. Distribution and dispersal in the Piping Plover. Auk 105:630638.

HePP, G. R., AND R. A. KenNAMER. 1993. Characteristics and consequences of nest-site fidelity in Wood Ducks. Auk 109:812-818.

KANTRUD, H. A., AND R. E. STEWART. 1984. Ecological distribution and crude density of breeding birds on prairie wetlands. Journal of Wildlife Management 48:426-437.

Lessells, C. M. 1984. The mating system of Kentish Plovers Charadrius alexandrinus. Ibis 126:474-483.

Lessells, C. M. 1985. Natal and breeding dispersal of Canada Geese (Branta canadensis). Ibis 127:3141.

Montalvo, S., AND J. Potri. 1992. Breeding dispersal in Spanish Pied Flycatchers Ficedula hypoleuca. Ornis Scandinavica 23:491-498.

Ollason, J. C., AND G. M. Dunnet. 1978. Age, experience and other factors affecting the breeding success of the Fulmar, Fulmarus glacialis, in Orkney. Journal of Animal Ecology 47:961-976.

ORING, L. W., AND D. B. LANK. 1982. Sexual selection, arrival times, philopatry, and site fidelity in the polyandrous Spotted Sandpiper. Behavioral Ecology and Sociobiology 10:185-191.

ORING, L. W., AND D. B. LANK. 1984. Breeding area fidelity, natal philopatry, and the social systems of sandpipers. Pages 125-147 in Shorebirds: Breeding behavior and populations. Behavior of marine animals, vol. 5. (J. Burger and B. L. Olla, Eds.). Plenum Press, New York.

Oring, L. W., D. B. LANK, AND S. J. Maxson. 1983. Population studies of the polyandrous Spotted Sandpiper. Auk 100:272-285.

$\rightarrow$ Page, G. W., L. E. Stenzel, AND C. A. Ribic. 1985. Nest site selection and clutch predation in thi Snowy Plover. Auk 102:347-353.

PAGe, G. W., L. E. STENZEL, W. D. SHuford, AND C. R. BRUCE. 1991. Distribution and abundance of the Snowy Plover on its western North American breeding grounds. Journal of Field Ornithology 62:245-255.

PAge, G. W., L. E. Stenzel, D. W. WinkLeR, AND C. W. SWARTH. 1983. Spacing out at Mono Lake: Breeding success, nest density, and predation in the Snowy Plover. Auk 100:13-24.

Page, G. W., M. A. Stern, ANd P. W. C. Paton. 1995. Geographic variation in wintering areas of Snowy Plovers from inland breeding sites in western North America. Condor 97:258-262.

PÄRT, T., AND L. GustafsSON. 1989. Breeding dispersal in the Collared Flycatcher (Ficedula albicollis): Possible causes and reproductive consequences. Journal of Animal Ecology 58: 305-320.

Paton, P. W. C. 1994. Survival estimates for Snowy Plovers breeding at Great Salt Lake, Utah. Condor 96:1106-1109.

Paton, P. W. C. 1995. Breeding biology of Snowy Plovers at Great Salt Lake, Utah. Wilson Bulletin 107:275-288.

Paton, P. W. C., AND T. C. EdWARDS, JR. 1990. Status and ecology of the Snowy Plover at Great Salt Lake-1990. Utah Birds 6:49-66.

PuRdue, J. R., AND H. HAINES. 1977. Salt water tolerance and water turnover in the Snowy Plover. Auk 94:248-255.

RITTINGHAUS, H. 1956. Untersuchungen am Seeregenpfeifer (Charadrius alexandrinus L.) auf der Insel Oldeoog. Journal für Ornithologie 97:117-115.

SCHAMEl, D., AND D. M. TRACY. 1977. Polyandry, replacement clutches, and site tenacity in the Red phalarope (Phalaropus fulicarius) at Barrow, Alaska. Bird-Banding 48:314-324.

SCHAMEL, D., AND D. M. TRACY. 1991. Breeding site fidelity and natal philopatry in the sex role-reversed Red and Red-necked phalaropes. Journal of Field Ornithology 62:390-398.

SHIELDS, W. M. 1982. Philopatry, inbreeding, and the evolution of sex. State University of New York Press, Albany.

STENZEL, L. E., J. C WARrineR, J. S. WARRINER, K. A. Wilson, F. Bidstrup, AND G. W. PAGE. 1994. Long-distance breeding dispersal of Snowy Plovers in western North America. Journal of Animal Ecology 63:887-902.

SZÉkElY, T., AND C. M. Lessells. 1993. Mate change in Kentish Plovers Charadrius alexandrinus. Ornis Scandinavica 24:317-322.

ThOMPSON, P. S., AND W. G. Hale. 1989. Breeding site fidelity and natal philopatry in the Redshank Tringa totanus. Ibis 131:214-224.

VAN HORNE, B. 1983. Density as a misleading indicator of habitat quality. Journal of Wildlife Management 47:893-901.

VICKERY, P. D., M. L. HUNTER, AND J. V. WELls. 1992. Is density an indicator of breeding success? Auk 109:706-710.

Warriner, J. S., J. C. Warriner, G. W. PAge, AND L. E. STENZEL. 1986. Mating system and reproduc- 
tive success of a small population of polygamous Snowy Plovers. Wilson Bulletin 98:15-37.

WESTERKOV, K. 1950. Methods for determining the age of game bird eggs. Journal of Wildlife Management 14:56-67.

Wiens, T. P., AND F. J. CUThbert. 1988. Nest-site tenacity and mate retention of the Piping Plover. Wilson Bulletin 100:545-553.

Wilson-JaCOBS, R., AND E. C. Meslow. 1984. Distribution, abundance and nesting characteristics of Snowy Plovers on the Oregon coast. Northwest Science 58:40-48. 